\title{
TITLE:
}

\section{ON THE POISONOUS SUBSTANCE CONTAINED IN HOLOTHURIANS}

$\operatorname{AUTHOR}(S)$ :

Yamanouchi, Toshihiko

\section{CITATION:}

Yamanouchi, Toshihiko. ON THE POISONOUS SUBSTANCE CONTAINED IN

HOLOTHURIANS. PUBLICATIONS OF THE SETO MARINE BIOLOGICAL LABORATORY 1955, 4(2-3): 183-203

ISSUE DATE:

1955-05-30

URL:

http://hdl.handle.net/2433/174528

RIGHT: 


\title{
ON THE POISONOUS SUBSTANCE CONTAINED IN HOLOTHURIANS ${ }^{1)}$
}

\author{
TOSHIHIKo YAMANOUCHI \\ Member of Educational Committee of Kyoto Prefecture; \\ Formally Lecturer of Zoology at Kyoto University \\ With 2 Text-figures \\ CONTENTS

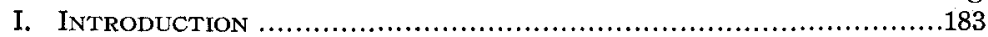 \\ II. Isolation and Purification of the Poison $\ldots . \ldots \ldots \ldots \ldots \ldots \ldots \ldots . .184$ \\ III. Chemical Nature of The Porson................................186 \\ IV. Action of the PoIson "Holothurin" on VARIOUS ANIMALs ...187 \\ a) On coelenterates, crustaceans and molluscs ....................187

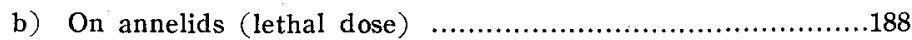 \\ c) On fishes (saponin and holothurin) ..........................188 \\ d) On amphibians (lethal dose) ...................................190

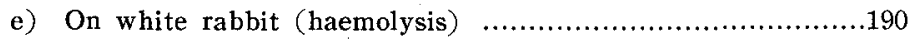 \\ f) On mouse (lethal dose) .....................................192 \\ V. Poisons of Holothurians in JaPAN and In South SEa ISlands...194

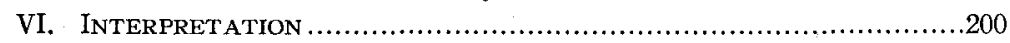

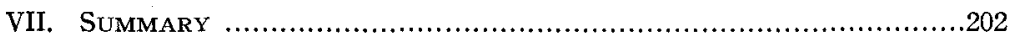 \\ Literature Cited................................................203
}

\section{Introduction}

In the summer of 1929 , when engaged in the experiment concerning cytolysis on epidermal cells of holothurians, the author found that marine fishes such as Enedrias nebulosus, Girella punctata and some others died within a few minutes, if the water extract of the tissues of Holothuria vagabunda SELENKA ${ }^{2)}$ was added to the aquarium. In this connection the following was the processes through which the poisonous extract was made:

(1) scraping the body surface of $H$. vagabunda with sharp knife,

(2) braying small pieces of the cylindrical body wall $i . e$. the flesh part in a mortar with washed sand,

1) Contributions from the Seto Marine Biological Laboratory, No. 253.

2) This species was originally described by BRANDT as Stichopus (Gymnochirota) leucospilota in 1835, and later by SELENKA as Holothuria vagabunda nov, sp. in 1867. The distribution and the anatomy of this animal in Japanese coast waters were reported in details by MrTsukURI in 1912.

Publ. Seto Mar. Biol, Lab., IV (2-3), 1955. (Article 16) 
(3) boiling pieces of body wall with sea water for about 5 minutes,

(4) cytolysing small pieces of the body wall with 0.4 mol. solution of kalium chloride.

A further research concerning holothurian poison had been interrupted for several years, but it was started again in the summer of 1941 . For five years from 1941 to 1945 , a series of experiments had been undertaken to clarify the nature of holothurian poison, especially of Holothuria vagabunda. In two years 1941 and 1942, about 140 kilogr. of Holothuria vagabunda was collected from the southwestern sea-shore of Wakayama Prefecture. From this collected material a new poison "Holothurin" was isolated in a crystallized form-chemically pure, and its chemical and physiological studies were executed. The new poison was found decidedly poisonous on many phylla of animals, especially on vertebrate animals.

The mechanism of poisoning on vertebrate animals has been made clear by a series of experiments to the effect that it is the destruction of red blood corpuscules or haemolysis. The existence of allied poisons has also been proved on another eatable and non-eatable 27 species of holothurians in Japan and in Palao Islands. The preliminary reports on this subject have been actually published in the following publications :

1) 1942. On the poisonous extract from holothurians. (in Japanese).

Teikoku Gakushiin Hôkoku, 1942, p. 73.

2) 1943. On the distribution of poison in the body of holothurians. (in Japanese). Zool. Magazine, vol. 55, p. 87.

3) 1943. On the poison contained in holothurians. (in Japanese).

Folia Pharmacologica Japonica, vol. 38, fasc. II, p. 115 \&.

This study has been carried out at Seto Marine Biological Laboratory of Kyoto University and at Ogiu Laboratory of Institute for Chemical Research of the same University. The author expresses his sincere thanks to Prof. D. MiYADI (the director of the former) and Prof. K. OGIU (the director of the latter) for their kind guidance and encouragement.

\section{Isolation and Purification of the Poison}

Holothuria vagabunda Selenka, inhabiting rocky sea-shore under tidal line, can be easily collected at the spring tide. In cold season (from September to April) this species migrates to deeper water and hibernates under stones. After taking off the viscera and the body fluid, the remaining thick body wall part of the flesh part consisting of epidermis, subepidermal connecting tissue, longitudinal and circular musculature, was washed by sea water and cut down to pieces. Adding possibly least amount of water, these pieces were boiled gently for about 15 minutes and filtrated. The filtrated brown colored water extract was further evaporated and condensed to viscious fluid on water bath. By adding $94 \%$ ethanol to this viscious fluid up to 
60-70\% alcohol content and then filtering, large amount of salt was separated. After this alcoholic solution was further distilled and condensed, large amount of absolute ethanol was added to the condensed extract up to $94 \%$ alcoholic content. White precipitate mainly composed of poison accompanying small amount of salt was thus obtained. As this poison is soluble in hot $94 \%$ ethanol but precipitates in cold one, hot crystallization in 94\% ethanol was repeated for several times (at least 3-4 times). Then the poison was separated as colorless minute crystals containing no impurity such as salt and other organic substance.

The colorless precipitate revealed under microscope minute uniform needle-shaped crystal as indicated in Figs. 1 and 2. As later indicated in details, this substance showed intense poisonous effect on various animals. For the detection of poisonous

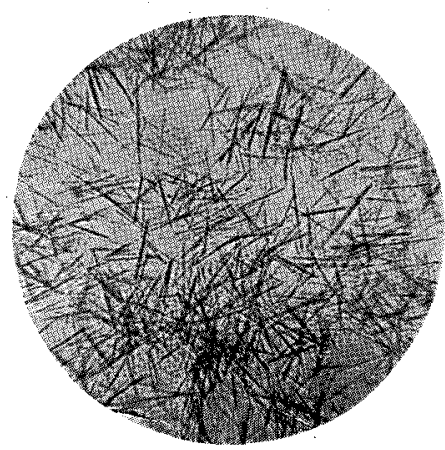

Fig. 1. Holothurin extracted from Holothuria vagabunda. Suddenly crystallized from the concentrated solution in hot $94 \%$ ethanol. $\times 30$.

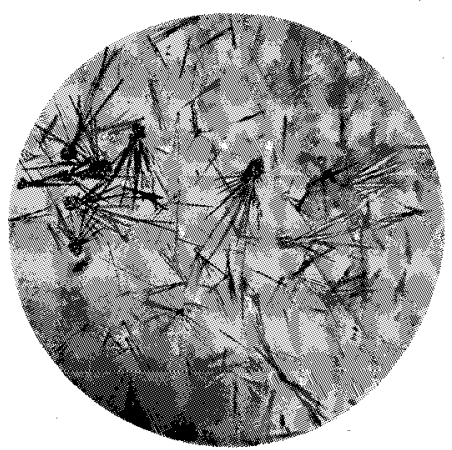

Fig. 2. Holothurin extracted from Holothuria vagabunda.

Slowly crystallized from the dilute solution in hot $94 \%$ ethanol. $\times 30$.

effect, a small fundulus-like fresh water fish, red variety of Oryzias latipes (about $2 \mathrm{~cm}$ in length) was used. This fish can be purchased from a fish farm in large numbers, and can be easily kept healthy in laboratory. A single fish can survive for several days in $10 \mathrm{ccm}$ water. This fish proved to be a very useful and convenient test animal for the detection of a poison soluble in water. The chemical nature of the poison is described in the following chapter.

The poison killed red var. of Oryzias latipes at $17^{\circ} \mathrm{C}$ in a solution of $1: 200,000$ $1: 250,000(0.0004-0.0005 \%)$ in 24 hours.

Yield of the poison.

\begin{tabular}{c|c|c|c|c}
\hline Year & $\begin{array}{c}\text { Weight of } \\
\text { fresh material }\end{array}$ & $\begin{array}{c}\text { Weight of poison } \\
\text { obtained }\end{array}$ & $\begin{array}{c}\text { Content of poison } \\
\text { for } 1 \mathrm{~kg} \text { material }\end{array}$ & $\begin{array}{c}\text { Poison/material } \\
\text { in \% }\end{array}$ \\
\hline 1941 & $22 \mathrm{~kg}$ & $11 \mathrm{gr}$ & $500 \mathrm{mg}$ & 0.05 \\
1942 & $46 \%$ & $37.4 \%$ & $800 \%$ & 0.08 \\
\hline
\end{tabular}


The part being used off in the preparation of poison, the viscera and the body fluid, were also found to contain poison, but in lesser degree than the body wall part. In 1942 , from $46 \mathrm{~kg}$ raw material (cylindrical body wall) $37.4 \mathrm{gr}$ poison was obtained. The body wall part is about half as heavy as of total body, therefore the whole body of the holothurian may contain about $0.05 \%$ poison instead of $0.08 \%$ as indicated in the lower row.

\section{Chemical Nature of the Poison}

A new poison has been found from Holoihuria vagabunda Serenka in the shape of colorless homogenous needle-like minute crystal (Figs. 1 and 2). It is hygroscopic and soluble in water at unlimited rate. It contains no crystal water. In fusion test (raising temperature at the rate of $2^{\circ} \mathrm{C}$ in $30^{\prime \prime}$ ) at $194^{\circ} \mathrm{C}$, it began to fuse partly, and at $206^{\circ} \mathrm{C}$ fused completely, but at the same time darkening accompanied gradually during fusion process. Therefore no definite fusion point measurement can be determined.

The water solution is colorless in dilute one, and in the condensed form it shows weak brownish color with yellow tint. The water solution is especially foaming or bubbling when stirred, and is resistant to heat and loses no poisonous effect on fish when boiled. It can not be dialized with ease through collodion membrane. It loses partly poisonous action by adsorption by animal charcoal. Large amount of animal charcoal is needed to abolish poisonous action completely. The minute crystals evoke strong sneeze when inhalated by nose. To a dog of medium size, piece of bread containing 50 or $100 \mathrm{mg}$ of poison was given. After eating bread, the dog ejected the eaten bread with large amount of foaming mucus. The dog refused farther to take food containing the poison. No detectable taste was found when applied to the tip of tongue.

At room temperature it solves in ethanol containing water, but not in $94 \%$ ethanol. It is neither soluble in absolute ethanol, nor in other organic solvents of any sort.

It consists of carbon, hydrogen and of oxygen, but not of nitrogen. By qualitative test, it was found to have contained sulfur, phophorus and halogen. The water solution is unable tó reduce Fehling's solution, but by acid hydrolysis it becomes to show positive reaction to Trommer and $\alpha$-naphthol test. $10 \mathrm{mg}$ of the crystallized poison was hydrolysed with $5 \mathrm{ccm} 5 \% \mathrm{HCl}$ solution for one hour. The acidified solution was transparent, but gat turbid by being precipitated as the flask was being warmed on boiling water bath. The filtrate of the acid hydrolysed product reduced Fehling's solution, producing large amount of reduced substance. After neutralisation by sodium carbonate, the filtrate lost poisonous action on fish completely. The precipitate or the aglycon was soluble in chloroform, ether, absolute ethanol, aceton and in benzol, but not in petroleum ether. 
$10 \mathrm{mg}$ poison was hydrolysed with $5 \mathrm{ccm} 5 \% \mathrm{NaOH}$ solution on boiling water bath for one hour. After hydrolysis it became viscious glycerin-like substance with lightly brownish yellow color, which showed no reaction to TROMMER and $\alpha$-naphthol test. However, the glycerin-like end product, after neutralisation by acid, retained poisonous action on fish, though more weakened than before hydrolysis was treated by alkali. The original poison killed red var. of Oryzias latipes within 30 minutes in $0.01 \%$ solution, whereas the hydrolysed one treated by alkali required more than 90 minutes to produce the same effect on the same condition.

Moreover the cause of the poisonous action of the substance in question is, as in the next chapter described in details, the destruction of red blood corpuscules or haemolysis.

As described above, the chemical and physiological natures of the poison can be summarized as follows :

(1) water soluble,

(2) strongly foaming by stirring,

(3) evoking strong sneeze to human nose when inhalated,

(4) resistant to heat (not decoposed at $100^{\circ} \mathrm{C}$ ),

(5) producing Fehling's solution reducing product by acid hydrolysis,

(6) having strong haemolytic action.

From these characteristics, it is reasonably concluded that the new poison extracted from Holothuria vagabunda SELENKa is very similar to plant glucoside saponin. The new poison may be estimated as a saponin-like compound of animal origin, and it may be named as "Holothurin".

\section{Action of the Poison "Holothurin" on Various Animals}

\section{a) On coelenterates, crustaceans and molluscs}

Coelenterata. Small pieces of the body wall of Holothuria vagabunda were boiled for 5 minutes with sea water of ten times in volume (for $10 \mathrm{gr}$ weight of tissue added $100 \mathrm{ccm}$ sea water). The brown-violet colored extract thus obtained was further diluted with sea water. The former extract is denoted for convenience $1: 10$ extract, the diluted one as $1: 1000$ extract, if the former was further diluted to 100 times.

Actinia equina. In $1: 300$ solution, gradual contraction. After 5 minutes total contraction (at $26.5^{\circ} \mathrm{C}$ ).

In $1: 1000$ solution, after 30 minutes contraction began.

Cavernularia obesa. In 1:450 solution contracted instataneously.

In $1: 4500$ solution, contracted feebly.

Crustacea. Marine crustacea Pachygrapsus crassipes, Metapenaeus sp. and Eupa- 
gurus samuelis exhibited no remarkable change when they were immersed in $1: 300$ extract.

Mollusca. Aplysia kurodai reacted same as crustaceans.

\section{b) On land earthworm (lethal dose)}

Six specimens of Eisenia foetida were put in the diluted solution of crystallized holothurin of various concentration. After 5 minutes immersion, they were taken out and washed with water and then placed in small petridish containing washed wet sand. After 24 hours they were examined to find whether alive or dead. Such experiments were accomplished with 150 animals.

Table 1. Immersion experiment of land earthworm Eisenia foetida in holothurin solution. Temp. $28^{\circ}-29^{\circ} \mathrm{C}$. For explanation see text.

\begin{tabular}{c|c|c|c|c|c}
\hline \hline $\begin{array}{c}\text { Holothurin } \\
\text { in } \%\end{array}$ & Dilution & $\begin{array}{c}\text { Number of } \\
\text { animals }\end{array}$ & \multicolumn{2}{|c|}{ After 24 hours } & \multicolumn{2}{c}{$\begin{array}{c}\text { Death rate } \\
\text { in } \%\end{array}$} \\
\hline 0.004 & $1: 25,000$ & 6 & 6 & 0 & 0 \\
0.005 & $1: 20,000$ & 12 & 12 & 0 & 0 \\
0.01 & $1: 10,000$ & 24 & 21 & 3 & 13 \\
0.011 & $1: 9,000$ & 12 & 1 & 11 & 92 \\
\hline 0.012 & $1: 8,000$ & 12 & 0 & 12 & 100 \\
0.014 & $1: 7,000$ & 12 & 0 & 12 & 100 \\
\hline
\end{tabular}

Thus the earthworms were killed within 24 hours by 5 minutes immersion in the solution of $0.012 \%(1: 8,000)$. Being put in the poisonous solution, the earthworms exhibited instantaneously vigorously movement, and then they fall in paralysis, losing reaction to external mechanical stimulus such as pinch by biceps.

\section{c) On fishes (saponin and holothurin)}

When small marine fishes were put together with Holothuria vagabunda in a small aquarium, they showed not any unusual behavior to each other, whenever the surface of the holothurian was injured mechanically by sharp knife, and as a result brown violet fluid diffused into water, the fishes lost equilibrium and swam about obliquely in the water. They came later to death accompanying total paralysis. The same was true when water extract of poison was added to the aquarium. Marine fishes such as Enedrias nebulosus, Girella punctata, Pomacentrus coelestis, Plotosus anguillaris and Thallosoma cupido exhibited such reaction to the poison. In fresh water fishes, Carasius auratus, gold fish, wild and red variety of Oryzias latipes were tested with poisonous extract and similar result as in the case of marine fishes was observed. The same was also true when either extract or the pure poison was injected into the muscle part of fish. 
As the mechanism of the poisonous action of holothurin revealed as haemolysis, it would be interesting if its action is compared with that of well known haemolytic reagent saponin. 5 fishes (red var. of Oryzias latipes) were put in a small finger bowel with $50 \mathrm{ccm}$ tap water containing various concentration of either holothurin or of saponin (Merck's preparation). Survival time from the beginning to the death of fishes was closely observed.

Table 2. Comparison of the poisonous action of holothurin and saponin. Temp. $23^{\circ} \mathrm{C}$. For explanation see text.

\begin{tabular}{|c|c|c|c|c|}
\hline \multirow{2}{*}{ Result } & \multirow{2}{*}{$\begin{array}{l}\text { Time interval } \\
\text { in hours }\end{array}$} & \multicolumn{2}{|c|}{ Concentration in dilution } & \multirow{2}{*}{$\begin{array}{l}\text { Ratio of concentration } \\
\text { to evoke the same effect } \\
\text { Saponin/Holothurin }\end{array}$} \\
\hline & & Saponin & Holothurin & \\
\hline All 5 fishes died & 1 & $1: 7,500$ & 1: 75,000 & $10: 1$ \\
\hline All 5 fishes died & 2 & $1: 10,000$ & $1: 100,000$ & $10: 1$ \\
\hline All 5 fishes died & 6 & $1: 20,000$ & $1: 250 ; 000$ & $12.5: 1$ \\
\hline 2 among 5 fishes died & 24 & $1: 30,000$ & $1: 300,000$ & $10: 1$ \\
\hline All 5 fishes died & 24 & $1: 25,000$ & $1: 250,000$ & $10: 1$ \\
\hline All 5 fishes alive & 24 & $1: 40,000$ & $1: 400,000$ & $10: 1$ \\
\hline
\end{tabular}

From Table 2, it is clear that holothurin acts as venom to fishes 10 times more stronger than the most powerful haemolytic reagent saponin hitherto known. In some fishes bloody gills were observed by holothurin poisoning, what indicates holothurin would have penetrate into the fish body through gills. Comparison of the survival time in various concentration shows also the same effect as the result shown in Table 2 .

Table 3. Comparison of the survival time in various concentration of venom. 10 fishes (red var. of Oryzias latipes) were put in $100 \mathrm{ccm}$ solution. Temp. $21.5^{\circ} \mathrm{C}$.

\begin{tabular}{l||c|c|c|c|c}
\hline Saponin solution & $1: 1,000$ & $1: 2,000$ & $1: 4,000$ & $1: 8,000$ & $1: 16,000$ \\
\hline $\begin{array}{c}\text { Range of survival time } \\
\text { in minutes }\end{array}$ & $17-28$ & $18-40$ & $25-47$ & $57-63$ & $185-255$ \\
\hline $\begin{array}{c}\text { Mean survival time in } \\
\text { minutes }\end{array}$ & 21.4 & 26 & 36.5 & 63 & 208 \\
\hline Holothurin solution & $1: 10,000$ & $1: 20,000$ & $1: 40,000$ & $1: 80,000$ & $1: 160,000$ \\
\hline $\begin{array}{c}\text { Range of survival time } \\
\text { in minutes }\end{array}$ & $17-34$ & $29-49$ & $34-53$ & $46-68$ & $135-200$ \\
\hline $\begin{array}{c}\text { Mean survival time in } \\
\text { minutes }\end{array}$ & 23.9 & 37.2 & 44.3 & 58.4 & 156 \\
\hline
\end{tabular}

In the course of poison test, it was revealed that the fresh water fish was more resistant to holothurian poison than the marine one, as follows: at $24.5^{\circ} \mathrm{C}$ the marine fish Enedrias nebulosus of the body length $3-4 \mathrm{~cm}$ died in holothurin solution of 
$1: 50,000(0.002 \%)$ within one hour, whereas the fresh water fish red var. of Oryzias latipes was killed in holothurin solution of $1: 400,000(0.00025 \%)$ within the same hour. The relative higher resistance of the fresh water fish to poison seems to be due to the lesser permeability of gills to external injurious chemical substance than the marine fish. The fresh water fish living in the stagnant water would be more adaptable to the variable chemical environment than the marine one.

\section{d) On amphibians (lethal dose)}

Into the abdominal cavity of Rana nigromaculata was injected small dose of holothurin solved in physiological salt solution. After 24 hours they were examined whether alive or dead.

Table 4. Lethal dose of holothurin to Rana nigromaculata.

For explanation see text.

\begin{tabular}{c|c|c|c|c}
\hline $\begin{array}{c}\text { Holothurin injected } \\
\text { mg pro 10 gr } \\
\text { body weight }\end{array}$ & $\begin{array}{c}\text { Ratio of holothurin } \\
\text { to body weight }\end{array}$ & $\begin{array}{c}\text { Number of } \\
\text { animals }\end{array}$ & $\begin{array}{c}\text { Died within } \\
24 \text { hours }\end{array}$ & $\begin{array}{c}\text { Death rate } \\
\text { in \% }\end{array}$ \\
\hline 0.1 & $1: 100,000$ & 6 & 0 & 0 \\
0.2 & $1: 50,000$ & 4 & 0 & 0 \\
\hline 0.4 & $1: 25,000$ & 10 & 2 & 20 \\
0.5 & $1: 20,000$ & 14 & 2 & 14 \\
0.6 & $1: 16,000$ & 7 & 3 & 43 \\
0.7 & $1: 14,000$ & 10 & 6 & 60 \\
1.0 & $1: 10,000$ & 8 & 7 & 88 \\
\hline 1.2 & $1: 8,300$ & 8 & 8 & 100 \\
3.0 & $1: 3,300$ & 3 & 3 & 100 \\
\hline
\end{tabular}

e) On white rabbit (haemolysis)

As already mentioned in the chapter III, holothurin seems to be a sort of saponinlike compound in its physical and chemical nature. With red blood corpuscules of white rabbit, a series of experiments on haemolysis were accomplished to prove above criterion. Blood was taken from the ear of white rabbit, and after defibrization serum was separated by centrifuge. Ppted. blood cells were washed three times with physiological salt solution, and $1 \%$ (sometimes 2\%) blood cells suspension in physiological salt solution was prepared.

Series of small test tubes with $5 \mathrm{ccm}$ red blood cells suspension containing poison of various concentrations, were placed in $38^{\circ} \mathrm{C}$ thermostat. After 30 minutes the grade of haemolysis was measured, and the threshold concentration for complete haemolysis was determined for both poisons holothurin and saponin.

From Table 5 it is clear that holothurin acts as haemolytica from 6 to 7 times stronger than saponin of Merck's preparation. In the previous experiment of fish, the former was about 10 times more powerful than the latter (Table 2 and 3). 
Table 5. Threshold concentration of holothurin and of saponin for complete haemolysis. Temp. $38^{\circ} \mathrm{C}$. For explanation see text.

\begin{tabular}{|c|c|c|c|c|c|}
\hline \multirow{2}{*}{$\begin{array}{l}\text { No. of } \\
\text { rabbit }\end{array}$} & \multirow{2}{*}{$\begin{array}{l}\text { Concentration } \\
\text { of blood cells } \\
\text { suspension }\end{array}$} & \multicolumn{2}{|c|}{$\begin{array}{l}\text { Threshold concentration for } \\
\text { complete haemolysis in } \%\end{array}$} & \multirow{2}{*}{$\begin{array}{l}\text { Ratio of threshold } \\
\text { concentration } \\
\text { Saponin/Holothurin }\end{array}$} & \multirow{2}{*}{$\begin{array}{l}\text { Mean of } \\
\text { ratio }\end{array}$} \\
\hline & & Saponin & Holothurin & & \\
\hline \multirow{5}{*}{ No. 2 9 } & \multirow{5}{*}{$1 \%$} & 0.0017 & 0.00024 & 7.2 & \multirow{5}{*}{6.31} \\
\hline & & 0.0017 & 0.00025 & 7.1 & \\
\hline & & 0.0018 & 0.00034 & 5.4 & \\
\hline & & 0.0022 & 0.00037 & 5.9 & \\
\hline & & 0.0018 & 0.00030 & 6.0 & \\
\hline \multirow{5}{*}{ No. $3 \hat{s}$} & \multirow{5}{*}{$1 \%$} & 0.0023 & 0.00034 & 6.7 & \multirow{5}{*}{6.62} \\
\hline & & 0.0023 & 0.00039 & 5.9 & \\
\hline & & 0.0022 & 0.00033 & 6.6 & \\
\hline & & 0.0023 & 0.00035 & 6.4 & \\
\hline & & 0.0023 & 0.00030 & 7.5 & \\
\hline \multirow{5}{*}{ No. $4 \$$} & \multirow{5}{*}{$1 \%$} & 0.0025 & 0.00030 & 8.3 & \multirow{5}{*}{7.15} \\
\hline & & 0.0021 & 0.00031 & 6.8 & \\
\hline & & 0.0022 & 0.00033 & 7.6 & \\
\hline & & 0.0022 & 0.00033 & 6.7 & \\
\hline & & 0.0023 & 0.00035 & 6.4 & \\
\hline \multirow[b]{2}{*}{. } & \multirow{5}{*}{$2 \%$} & 0.0030 & 0.00035 & 8.6 & \multirow{5}{*}{7.58} \\
\hline & & 0.0030 & 0.00040 & 7.5 & \\
\hline No. $4 \hat{8}$ & & 0.0031 & 0.00040 & 7.8 & \\
\hline & & 0.0032 & 0.00045 & 7.0 & \\
\hline & & 0.0032 & 0.00045 & 7.0 & \\
\hline
\end{tabular}

As well known, haemolytic action of saponin is reduced by cholesterin, and it is also generally accepted that such reduction in action may be due to the combination of saponin to cholesterin in blood (RANSOM 1901). To prove saponin-like nature of holothurin, the following experiment was undertaken. A small amount of cholesterin dissolved in ether was added to the dilute solution of holothurin, and test tubes containing mixed solution of holothurin and cholesterin were immersed in boiling water for 30 minutes in order to drive off ether completely. After cooling, sufficient amount of red blood cells suspension was added to the test tubes to hold $1 \%$ blood cells concentration in $10 \mathrm{ccm}$ volume, and then the content of the test tubes was made $10 \mathrm{ccm}$ by adding further sufficient amount of physiological salt solution.

Table 6 indicates that the threshold concentration of holothurin for complete haemolysis is $0.00034 \%(+++)$, but when $0.0005 \%$ of cholesterin is present, this value increases to $0.001 \%(+++)$, and by the presence of $0.001 \%$ cholesterin it becomes $0.0018 \%(+++)$, that is the action of holothurin for haemolysis is remarkably reduced by cholesterin, and this antitoxic action of cholesterin is roughly proportionally to the amount of cholesterin present. Therefore it may be reasonably 
Table 6. Comparison of haemolytic action of holothurin and holothurin mixed with cholesterin. Temp. $38^{\circ} \mathrm{C}$.,,++++- indicate complete, incomplete and no haemolysis respectively.

\begin{tabular}{|c|c|c|c|c|}
\hline $\begin{array}{l}\text { No. of } \\
\text { rabbit }\end{array}$ & $\begin{array}{l}\text { Interval of } \\
\text { haemolysis } \\
\text { in minutes }\end{array}$ & $\begin{array}{l}\text { Threshold concentration } \\
\text { of holothurin for com- } \\
\text { plete haemolysis in } \%\end{array}$ & $\begin{array}{l}\% \text { of holothurin solu- } \\
\text { tion for haemolysis } \\
\text { mixed with } 0.0005 \% \\
\text { cholesterin }\end{array}$ & $\begin{array}{l}\% \text { of holothurin solu } \\
\text { tion for haemolysis } \\
\text { mixed with } 0.001 \% \\
\text { cholesterin }\end{array}$ \\
\hline No. 2 우 & 30 & $0.0003+t+$ & $\begin{array}{lc}0.001 & ++t \\
0.0005 & +\end{array}$ & . \\
\hline No. 38 & 60 & $0.0004+++$ & $\begin{array}{cc}0.0009 & +++ \\
0.0006 & -\end{array}$ & $\begin{array}{cc}0.0018 & +++ \\
0.0015 & -\end{array}$ \\
\hline No. 2 우 & 60 & $0.0003+t+$ & $\begin{array}{lc}0.001 & +++ \\
0.00075 & -\end{array}$ & $\begin{array}{l}0.00175+t+ \\
0.0015\end{array}$ \\
\hline No. 3t & 60 & $0.00035+++$ & $\begin{array}{l}0.00125+++ \\
0.001+ \\
0.00075 \stackrel{+}{-}\end{array}$ & $\begin{array}{l}0.00175+++ \\
0.0015 \stackrel{+}{0.00125+}\end{array}$ \\
\hline No. $3 t$ & 60 & $0.00035+t+$ & $\begin{array}{lc}0.001 & +t+ \\
0.00075 & -\end{array}$ & 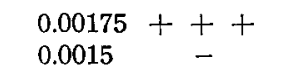 \\
\hline \multicolumn{2}{|c|}{ Mean } & $0.00034+++$ & $\begin{array}{l}0.001 \\
0.00067\end{array}++$ & $\begin{array}{l}0.0018 \\
0.0014\end{array}++$ \\
\hline
\end{tabular}

concluded that pharmacological action of holothurin may be similar to that of saponin, or that holothurin may be estimated as animal saponin as compared with plant one.

\section{f) On mouse (lethal dose)}

To determine the lethal dose of holothurin, crystallized holothurin was applied to mouse either by peros application, or subcutaneous and intravenous injection. 249 mice were used for such experiments, and the result is summarized in Tables 7, 8, 9 and 10.

Table 7. Lethal dose of holothurin by intravenous injection of holothurin to the tail vein of mouse.

\begin{tabular}{|c|c|c|c|c|c|c|c|c|}
\hline \multirow{2}{*}{$\begin{array}{l}\text { mg of holothurin } \\
\text { injected pro } \\
10 \mathrm{gr} \text { body weight }\end{array}$} & \multirow{2}{*}{$\begin{array}{c}\text { Ratio of } \\
\text { Holothurin } \\
\text { /body weight }\end{array}$} & \multirow{2}{*}{$\begin{array}{c}\text { Number } \\
\text { of } \\
\text { mice }\end{array}$} & \multicolumn{6}{|c|}{$\begin{array}{l}\text { Number of mice died within } \\
\text { the hours indicated }\end{array}$} \\
\hline & & & $1 \mathrm{~h}$ & $2 \mathrm{~h}$ & $6 \mathrm{~h}$ & $24 \mathrm{~h}$ & $48 \mathrm{~h}$ & $72 \mathrm{~h}$ \\
\hline 0.0015 & $1: 6,660,000$ & 6 & 0 & 0 & 0 & 1 & 1 & 0 \\
\hline 0.0025 & $1: 4,000,000$ & 18 & 0 & 0 & $\mathbf{1}$ & 0 & 0 & 2 \\
\hline 0.00375 & $1: 3,000,000$ & 12 & 0 & 0 & 5 & 1 & 2 & 1 \\
\hline 0.005 & $1: 2,000,000$ & 18 & 0 & 0 & 5 & 3 & 0 & 1 \\
\hline 0.00625 & $1: 1,600,000$ & 12 & 0 & 0 & 5 & 3 & 4 & \\
\hline 0.0075 & $1: 1,330,000$ & 12 & 0 & 3 & 7 & 2 & & \\
\hline 0.01 & $1: 1,000,000$ & 12 & 0 & 0 & 6 & 6 & & \\
\hline 0.015 & 1: $\quad 666,000$ & 6 & 3 & 1 & 1 & 1 & & \\
\hline 0.025 & $1: 400,000$ & 6 & 5 & $\mathbf{1}$ & & & & \\
\hline
\end{tabular}


Table 8. Subcutaneous injection of holothurin to mouse.

\begin{tabular}{c|c|c|c|c|c|c|c|c}
\hline $\begin{array}{c}\text { mg of holothurin } \\
\text { injected pro } \\
\text { 10 gr body weight }\end{array}$ & $\begin{array}{c}\text { Ratio of } \\
\text { Holothurin } \\
\text { /body weight }\end{array}$ & $\begin{array}{c}\text { Number } \\
\text { of } \\
\text { mice }\end{array}$ & \multicolumn{5}{|c|}{$\begin{array}{c}\text { Number of mice died within } \\
\text { the hours indicated }\end{array}$} \\
\hline 0.1 & $1: 100,000$ & 9 & 0 & 0 & 0 & 0 & 0 & 0 \\
0.2 & $1: 50,000$ & 21 & 0 & 0 & 0 & 1 & 4 & 2 \\
0.3 & $1: 33,300$ & 13 & 0 & 0 & 0 & 6 & 2 & 0 \\
0.4 & $1: 25,000$ & 12 & 0 & 0 & 0 & 6 & 2 & 1 \\
0.5 & $1: 20,000$ & 6 & 0 & 0 & 0 & 4 & 0 & 0 \\
0.6 & $1: 16,600$ & 6 & 0 & 0 & 0 & 4 & 0 & 0 \\
\hline 0.7 & $1: 14,300$ & 6 & 0 & 0 & 0 & 6 & & \\
1.0 & $1: 10,000$ & 12 & 0 & 0 & 3 & 9 & & \\
2.0 & $1: 5,000$ & 7 & 0 & 0 & 5 & 2 & & \\
\hline
\end{tabular}

Table 9. Peros application of holothurin to mouse.

\begin{tabular}{c|c|c|c|c|c|c|c|c}
\hline \hline \multirow{2}{*}{$\begin{array}{c}\text { mg of holothurin } \\
\text { peros given pro } \\
10 \text { gr body weight }\end{array}$} & $\begin{array}{c}\text { Ratio of } \\
\text { Holothurin } \\
\text { /body weight }\end{array}$ & $\begin{array}{c}\text { Number } \\
\text { of } \\
\text { mice }\end{array}$ & \multicolumn{5}{|c|}{$\begin{array}{c}\text { Number of mice died within } \\
\text { the hours indicated }\end{array}$} \\
\cline { 4 - 8 } 0.5 & $1: 20,000$ & 6 & 0 & 0 & 0 & 0 & 0 & 0 \\
0.75 & $1: 13,000$ & 6 & 0 & 0 & 1 & 0 & 1 & 0 \\
1.0 & $1: 10,000$ & 6 & 0 & 0 & 0 & 0 & 0 & 0 \\
1.25 & $1: 8,000$ & 6 & 0 & 0 & 0 & 0 & 0 & 0 \\
1.5 & $1: 6,600$ & 6 & 0 & 0 & 1 & 0 & 0 & 0 \\
2.0 & $1: 5,000$ & 6 & 0 & 0 & 1 & 2 & 0 & 0 \\
2.5 & $1: 4,000$ & 6 & 1 & 0 & 1 & 1 & 0 & 0 \\
3.0 & $1: 3,300$ & 6 & 0 & 1 & 1 & 2 & 0 & 0 \\
4.0 & $1: 2,500$ & 6 & 2 & 2 & 0 & 2 & & \\
\hline
\end{tabular}

Table 10. Comparison of the lethal dose of holothurin to mouse, died within 24 hours by different modes of application.

\begin{tabular}{c|c|c|c}
\hline Mode of application & $\begin{array}{c}\text { mg of holothurin pro } \\
10 \mathrm{gr} \text { body weight } \\
\text { of mouse }\end{array}$ & $\begin{array}{c}\text { Ratio of lethal dose } \\
\text { to body weight }\end{array}$ & $\begin{array}{c}\text { Relative ratio } \\
\text { of lethal dose }\end{array}$ \\
\hline Intravenous injection & 0.0075 & $1: 1,330,000$ & 1 \\
\hline Subcutaneous injection & 0.7 & $1: 14,300$ & 93 \\
\hline Peros applicetion & 4.0 & $1: 2,500$ & 532 \\
\hline
\end{tabular}


The symptoms of the intoxicated mice. After the application of holothurin, the mice lost compensation in locomotory movement, and then there came paralysis in which the fore legs were attacked at first, and later followed by the hind ones. Reaction to mechanical stimulus, such as insert by biceps, was totally lost. When the paralysed mice placed on their back position, they were no more able to do righting reaction. In some animals nose bleeding due to lung blooding was observed.

The anatomical appearance of the intoxicated mice. By dissecting carcass, the intoxicated mice showed generally hyperaemia on thoracic and abdominal cavity surface, on intestinal outer surface, on liver and milz, and blooding in lungs. By subcutaneous injection of holothurin, the injected region showed injuratio accompanying oedem, and surrounding part became congested. In animals peros holothurin given, gas was filled in stomach and intestine, and the interior of the latter was filled with mucus like viscious fluid.

\section{Poisons of Holothurians in Japan and in South Sea Islands}

In South Sea Islands, holothurians are not unusual food for the natives, for instance in Palao Islands among $12 \mathrm{spp}$. of holothurians commonly found in coral reefs, $10 \mathrm{spp}$. are adopted as food by the natives. In Japan two spp. (Stichopus japonicus and Cucumaria japonica) are sold at market in winter season. Moreover holothurians are prepared as trépang (haishên) and are exported to China from Japan and South Sea

Table 11. Relative grade of venom contained in the holothurians inhabiting the Japanese coast waters.

\begin{tabular}{|c|c|c|c|}
\hline Animal & $\begin{array}{c}\text { Grade of } \\
\text { venom for fish }\end{array}$ & $\begin{array}{l}\text { Grade of haemolysis } \\
\text { for rabbit red } \\
\text { blood cells }\end{array}$ & Locality \\
\hline Holothuria vagabunda & $++t$ & +++ & Seto \\
\hline H. monacaria & +++ & +++ & $"$ \\
\hline H. lubrica & $+\quad+$ & +++ & $”$ \\
\hline H. pervicax. & - & - & " \\
\hline Stichopus japonicus & + & + & " \\
\hline St. oshimae & - & - & $"$ \\
\hline Cucumaria japonica & + & + & Onagawa \\
\hline C. sp. & ++ & ++ & " \\
\hline C. echinata & + & + & $”$ \\
\hline Pentacta australis & + & + & $"$ \\
\hline Pseudocucumis africana & $+\div+$ & ++ & Seto \\
\hline Caudina chilensis & + & $-?$ & Asamushi \\
\hline Molpadia sp. & - & - & Onagawa \\
\hline Polycheira rufescens & +++ & +++ & Seto \\
\hline Leptosynapta ooplax & +++ & ++1 & $"$ \\
\hline
\end{tabular}


Islands. In the preparation of trépang, gutted holothurians are firstly boiled in water, and then dried in the air by sun light. It is certainly a necessary and interesting problem to investigate whether other holothurians contain similar poisonous substance as holothurin or not.

Fresh material was collected at several marine biological stations in Japan, Seto (Kyoto University), Onagawa (Tohokiu Univ.) and Asamushi (Tohoku Univ.). When it was unable to accomplish precise experiment at seashore, gutted holothurians were weighed and conserved in alcohol. Such material was later warmed on water bath to expel alcohol, and then water extract was prepared. For the test of holothurians in South Sea Islands, trépang which was brought by the author from Palao Islands in 1941, was utilized.

For the detection of poison contained in holothurians, two methods were adopted. 1) Small pieces of the body wall of holothurians were cut off, and after weighing they were boiled with water for about 5 minutes, water extract thus obtained was if necessary further diluted with water. In such extracted solution, reaction of marine or of fresh water fishes was observed. 2) Haemolytic action of extract on rabbit red blood cells was observed.

For the detection of poisonous substance of trépang preparation, thin flakes of each sort were boiled with water of 100 times in weight, and thus $1: 100$ water extract of trépang was prepared. The survival time of red var. of Oryzias latipes in these solutions was measured (10 fishes in $100 \mathrm{ccm}$ water extract).

Table 12. Venom of trépang preparation in Japan and in South Sea Islands. Survival time of red var. of Oryzias latipes in 1:100 extract was measured. Temp. $21.5^{\circ}-22.5^{\circ} \mathrm{C}$.

\begin{tabular}{l|c|c|c}
\hline \multicolumn{1}{c|}{ Animal } & Number of fishes & $\begin{array}{c}\text { Mean survival time of } \\
\text { fish in minutes }\end{array}$ & $\begin{array}{c}\text { Grade of } \\
\text { venom }\end{array}$ \\
\hline Holothuria atra & 24 & 26 & +++ \\
H. scabra & 24 & 48 & + \\
H. bivittata & 24 & 42 & + \\
H. argus & 24 & 37 & + \\
H. sp. & 41 & 34 & + \\
H. lecanora var. & 25 & 37 & + \\
H. nobilis & $41^{*}$ & $116+\mathrm{X}$ & + \\
H. axiologa & 24 & 25 & + \\
\hline Stichopus variegatus & 24 & 29 & + \\
St. chloronotus & 30 & 34 & + \\
St. japonicus & 41 & 59 & + \\
Parastichopus nigripunctatus & 34 & 173 & + \\
\hline Cucumaria japonica & 14 & 34 & + \\
\hline Thelenota ananas & 49 & 28 & + \\
\hline
\end{tabular}

* 13 fishes among 41 survived longer than 360 minutes, and were excluded from the mean. 
Table 13. Grade of venom of trépang preparation measured by the time for complete haemolysis. inst. denotes instataneous haemolysis; trace, + denote trace and partial haemolysis respectively in 3 hours. - denotes no haemolysis.

\begin{tabular}{|c|c|c|c|c|c|}
\hline \multirow{3}{*}{ Animal } & \multirow{2}{*}{\multicolumn{4}{|c|}{$\begin{array}{l}\text { Time for complete haemolysis } \\
\text { in minute and second } \\
\text { mount of extract }(1: 100) \text { added to } \\
\text { ccm } 1 \% \text { blood cells suspension }\end{array}$}} & \multirow{3}{*}{ Grade of venom } \\
\hline & & & & & \\
\hline & $2 \mathrm{ccm}$ & $1.0 \mathrm{ccm}$ & $0.5 \mathrm{ccm}$ & $0.25 \mathrm{ccm}$ & \\
\hline Holothuria atra & inst & $10^{\prime \prime}$ & $20^{\prime \prime}$ & $60^{\prime \prime}$ & +++ \\
\hline H. scabra & inst & $3^{\prime} 30^{\prime \prime}$ & $15^{\prime}$ & + & + \\
\hline H. bivittata & inst & $3^{\prime}$ & $15^{\prime}$ & + & + \\
\hline H. $\operatorname{argus}$ & inst & $30^{\prime \prime}$ & $1^{\prime} 40^{\prime \prime}$ & $8^{\prime}$ & ++ \\
\hline$H$. sp. & inst & $1^{\prime} 20^{\prime \prime}$ & $3^{\prime}$ & $20^{\prime}$ & ++ \\
\hline$H$. lecanora var. & inst & $50^{\prime \prime}$ & $2^{\prime} 30^{\prime \prime}$ & $8^{\prime}$ & ++ \\
\hline H. nobilis & trace & - & - & - & $-?$ \\
\hline H. axiologa & inst & $20^{\prime \prime}$ & $70^{\prime \prime}$ & $3^{\prime}$ & +++ \\
\hline Stichopus variegatus & inst & $12^{\prime \prime}$ & $40^{\prime \prime}$ & $3^{\prime}$ & +++ \\
\hline St. chloronotus & inst & $30^{\prime \prime}$ & $70^{\prime \prime}$ & $2^{\prime} 40^{\prime \prime}$ & +++ \\
\hline St. japonicus & inst & $15^{\prime}$ & + & trace & + \\
\hline $\begin{array}{l}\text { Parastichopus } \\
\quad \text { nigripunctatus }\end{array}$ & + & + & trace & - & + \\
\hline Cucumaria japonica & inst & $5^{\prime}$ & $30^{\prime}$ & + & + \\
\hline Thelenota ananas & inst & $10^{\prime \prime}$ & $20^{\prime \prime}$ & $1^{\prime} 20^{\prime \prime}$ & +++ \\
\hline
\end{tabular}

Table 14. Combining the results shown in the tables 12 and 13 , the relative grade of venom contained in trépang preparation is presented.

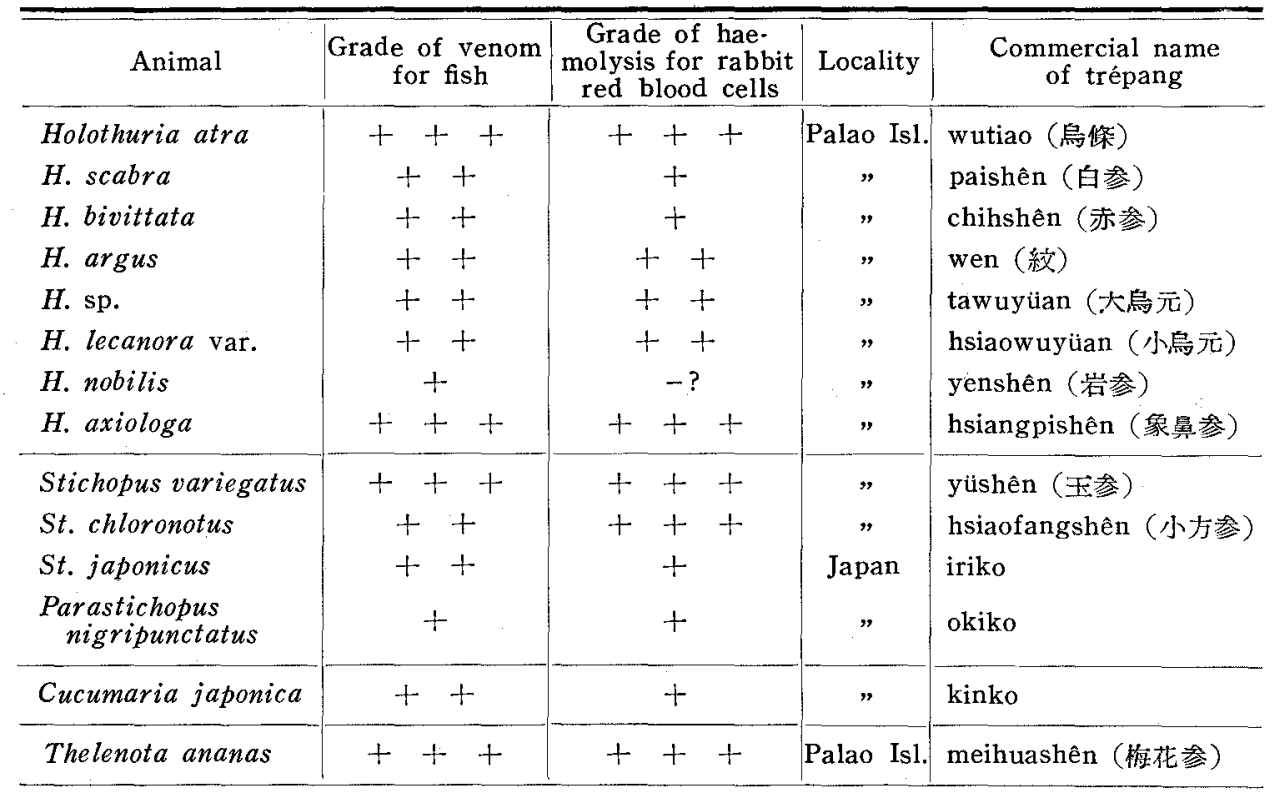


Table 15. List of $27 \mathrm{spp}$. of holothurians in Japan and in South Sea Islands as to whether they contain poison or not. Summarized from the tables 11 and 14 .

\begin{tabular}{|c|c|c|c|c|}
\hline Animal & $\begin{array}{l}\text { Poison } \\
\text { for fish }\end{array}$ & $\begin{array}{l}\text { Haemolysis for } \\
\text { rabbit blood cells }\end{array}$ & Habitat & $\begin{array}{c}\text { Local name of holo- } \\
\text { thurians in Palao } \\
\text { Islands }\end{array}$ \\
\hline Holothuria vagabunda & + & + & Seto & \\
\hline H. monacaria & + & + & " & \\
\hline H. lubrica & + & + & ” & \\
\hline H. pervicax & - & - & " & \\
\hline H. atra & + & + & Palao Isl. & chauas \\
\hline H. scabra & + & + & $"$ & molch \\
\hline H. bivittata & + & + & ” & molch \\
\hline$H$. argus & + & + & $"$ & bibak madal \\
\hline H. lecanora var. & + & + & ” & karamrm \\
\hline$H$. sp. & + & + & $"$ & ngallau \\
\hline H. nobilis & + & $-?$ & $"$ & bad le chaled \\
\hline H. axiologa & + & + & $"$ & molch \\
\hline Stichopus japonicus & + & + & Seto & \\
\hline St. oshimae & - & - & $"$ & \\
\hline St. variegatus & + & + & Palao Isl. & blaom \\
\hline St. chloronotus & + & + & " & ngkasugl \\
\hline $\begin{array}{l}\text { Parastichopus } \\
\text { nigripunctatus }\end{array}$ & + & + & Japan Sea & \\
\hline Cucumaria japonica & + & $t$ & Onagawa & \\
\hline C. sp. & + & $t$ & $"$ & \\
\hline C. echinata & + & + & $"$ & \\
\hline Pentacta australis & + & + & " & \\
\hline Pseudocucumis africana & + & + & Seto & \\
\hline Caudina chilensis & + & $-?$ & Asamushi & \\
\hline Molpadia sp. & - & - & Onagawa & : \\
\hline Polycheira rufescens & + & + & Seto & \\
\hline Leptosynapta ooplax & + & + & $"$ & \\
\hline Thelenota ananas & + & + & Palao Isl. & tamataml \\
\hline $\begin{array}{l}\text { Number of species } \\
\text { containing poison }\end{array}$ & 24 & 22 & \multirow{2}{*}{\multicolumn{2}{|c|}{$\begin{array}{l}\% \text { of species containing } \\
\text { poison } 24 / 27 \times 100=89 \%\end{array}$}} \\
\hline $\begin{array}{l}\text { Number of species } \\
\text { containing no poison }\end{array}$ & 3 & 5 & & \\
\hline
\end{tabular}


To compare haemolytic action, different amounts from 0.25 to $2 \mathrm{ccm}$ of the water extract $(1: 100)$ of each trépang preparation was added to $5 \mathrm{ccm} 1 \%$ red blood cells suspension of rabbit. The water extract was made to contain $0.9 \%$ sodium chloride by adding sufficient amount of salt. The time to complete haemolysis was measured by stop watch.

Among 27 species of which 16 are from Japanese water, and 11 from South Sea Islands, 24 species contain substance venomous to fish and 22 species to rabbit red blood cells, or more than $80 \%$ holothurian species were found containing poisons of various strength. It may be maintained that holothurians generally contain poison with a few exceptions. Each species seems to contain chemically different poison notwithstanding its physiological action is alike. In Table 16, solubility of holothurian poisons in ethanol is compared.

Table 16. Solubility of holothurian poisons in ethanol at room temperature. sol and ppt denote soluble and insoluble respectively.

\begin{tabular}{l|c|c|c|c|c|c}
\hline \multirow{2}{*}{ Animal } & \multicolumn{7}{|c}{ Percentage of ethanol } \\
\cline { 2 - 7 } & 0 & 50 & 55 & 90 & 94 & 100 \\
\hline Holothuria vagabunda & sol & sol & sol & sol & ppt & ppt \\
Stichopus japonicus & sol & sol & sol & sol & sol & sol \\
Cucumaria japonica & sol & sol & sol & sol & ppt & ppt \\
Polycheira rufescens & sol & sol & ppt & ppt & ppt & ppt \\
Caudina chilensis & sol & sol & sol & sol & sol & sol \\
\hline
\end{tabular}

Poisons of Holothuria vagabunda and Cucumaria japonica show same solubility to alcohol, but the minimal concentration for complete haemolysis of $1 \%$ red blood cells suspension in 30 minutes was in $H$. vagabunda $0.0002-0.0004 \%$, and in C. japonica $0.001 \%$. Caudina chilensis and Stichopus japonicus contain poison soluble to absolute alcohol, but the venom of the former was decidedly stronger than the latter. From these facts it is clear that the various poisons contained in holothurians are specific to each species. The grade of venom and also the presence or absence of the poison in various species of holothurians are independent of the genus to which each holothurian belongs as indicated in Tables 11, 14 and 15.

Distribution of poison in the body of holothurians. The body wall or the flesh part of holothurians has been proved to be poisonous to various animals. In order to know whether the other part of the body contains poison or not, the following procedure was adopted. Several organs of holothurians were separated and weighed, and then boiled with water of 10 parts for 10 minutes. The water extract was diluted with the same volume of water; thus 1:20 extract was prepared. In each extracted solution of $100 \mathrm{ccm}, 7$ fishes (red var. of Oryzias latipes) were put and the survival time from immersion to death was observed. The venom of the different organs was also measured by haemolytic method, in which one ccm of $1: 10$ extract 
of each organ containing $0.9 \%$ salt was added to $5 \mathrm{ccm}$ of $1 \%$ rabbit red blood cells suspension, and the time for complete haemolysis was measured.

Table 17. Venom in different organs of Holothuria vagabunda.

\begin{tabular}{l|c|c|c}
\hline \multicolumn{1}{|c|}{ Part of body } & $\begin{array}{c}\text { Mean survival time of } \\
\text { seven O. latipes in } \\
1: 20 \text { extract }\end{array}$ & $\begin{array}{c}\text { Time for complete } \\
\text { haemolysis } \\
\text { in minute \& second }\end{array}$ & $\begin{array}{c}\text { Water content } \\
\text { in \% }\end{array}$ \\
\hline Body wall & 15.8 minute & $13^{\prime \prime}$ & 89 \\
Cuvier's organ & $16.4 "$ & $10^{\prime \prime}$ & 91 \\
Intestinal haemal & $17.4 "$ & $1^{\prime} 30^{\prime \prime}$ & 83 \\
$\quad$ vessels & $28.1 "$ & $15^{\prime}$ & 90 \\
Digestive canal & $43.6 "$ & $10^{\prime}$ & 80 \\
Longitudinal muscle & $48.0, "$ & $2^{\prime}$ & - \\
Ovarium & 24 & 26.5 & \\
\hline
\end{tabular}

As the water content of each part or organ varies from 80 to $90 \%$, the difference in survival times of fish in each extract indicates clearly the varied content of holothurin in each organ.

The body fluid of $H$. vagabunda also contains poison. Body fluid from a single individium was divided into two equal parts ( $a$ and $b$ ):

a-part was boiled for a few seconds in order to destruct blood cells; in b-part blood cells were precipitated by centrifuge, and the precipitate was boiled with the same volume of sea water; c-part was prepared by boiling the filtrate of b-part.

$\mathrm{a}, \mathrm{b}$ and $\mathrm{c}$ were diluted with 4 parts of sea water. The venom of these three parts ( $\mathrm{a}, \mathrm{b}$ and c) was measured with the marine fish Enedrias nebulosus.

Table 18. The venom of the body fluid of Holothuria vagabunda. Marine fish Enedrias nebulosus was put in diluted fluid and the survival time was observed. For one fish $50 \mathrm{ccm}$ solution.

\begin{tabular}{c|c|c|c|c|c}
\hline $\begin{array}{c}\text { No. of } \\
\text { experiment }\end{array}$ & $\begin{array}{c}\text { Temp. } \\
\text { in C }\end{array}$ & $\begin{array}{c}\text { Number } \\
\text { of fish }\end{array}$ & \multicolumn{3}{|c}{ Mean survival time in minute } \\
\hline 1 & 27 & 12 & $\begin{array}{c}\mathrm{a} \\
\text { (whole body fluid) }\end{array}$ & (blood cells only) & $\begin{array}{c}\text { c } \\
\text { (serum only) }\end{array}$ \\
\hline 2 & 27 & 18 & 19.3 & 21.5 & 78 \\
3 & 28.5 & 15 & 23.7 & 21.7 & 150 \\
4 & 28.5 & 18 & 15.6 & 18.0 & 38.2 \\
5 & 27 & 21 & 17.3 & 16.3 & 49.5 \\
& & 21.4 & 24.7 & 50.7 \\
\hline
\end{tabular}

The survival times of fishes are almost equal in the whole body fluid and in the blood cells only. In Holothuria vagabunda the major part of poison holothurin 
is located in blood cells, but the minor part is also present in serum. The body fluid is able to haemolyse red blood cells of rabbit. When $1 \mathrm{ccm}$ body fluid was after boiling added to $5 \mathrm{ccm} 1 \%$ blood cells suspension of rabbit, the blood cells underwent complete haemolysis in $2^{\prime} 20^{\prime \prime}$ at $26.5^{\circ} \mathrm{C}$. The distribution of poison in this holothurian extends to every organ including body fluid, though somewhat different in content between organs (Table 17). The function of the poison holothurin in the metabolism of holothurians is not clear at present, as it has not yet been investigated.

In some animals other than holothurians, test was made as to the existence of poisonous substance to fish at Seto Marine Biological Laboratory. Only the starfish Asterina pectinifera proved to contain substance poisonous to fish, though somewhat one-tenth so weak as compared with the poison of Holothuria vagabunda. On the same condition at $27^{\circ}-28^{\circ} \mathrm{C}$.

Asterina pectinifera-1:100 extract killed Girella punctata in 48 minutes.

Holothuria vagabunda-1:300 extract killed the above fish in 12 minutes.

\section{Interpretation}

In Japan two species of holothurians, Stichopus japonicus and Cucumaria japonica are eaten raw. Nevertheless, no case is hitherto reported concerning poisoning. The reason of this may be assumed as follows:

(1) These edible species contain weaker poison than the unedible species such as Holothuria vagabunda and $H$. monacaria (Table 11 ). Even the species containing strong poison would be harmless, so far as being not too much eaten.

(2) Holothurian poison is most dangerous when it enters into blood circulation (haemolysis), but it is not so harmful when eaten. From Table 10 the relative lethal dose of holothurin for mouse is as follows:

$\begin{array}{lr}\text { intravenous injection } & 1 \\ \text { subcutaneous injection } & 93 \\ \text { peros application } & 532\end{array}$

(3) As reported in the chapter III, holothurin loses completely poisonous action by acid hydrolysis. Some part of eaten poison may undergo decomposition by peptic acid during digestion and weaken in poisonous action.

From these standpoints holothurians do not seem to be harmful food. On the other hand, holothurian poison may exert more or less useful effect as food, in so much as saponin or allied substance would be needed, because holothurin or allied poison is from its chemical and physiological natures considered as saponin-like compound. In Japanese coast waters there dwell about 40 species of holothurians (excepting deep water fauna), 16 species among them have been examined as to poisonous substance (Table 11). The edible two species would become eatable because of their having thick body wall and of good taste, and the other species 
would have become untouched as food because of their unsavouriness or of bitter taste or of their poisonous effect learned by long experience since prehistoric ancient time.

Stichopus japonicus is a popular diet in Japan in winter season. It contains poison, but its venom is so weak as such that 1:20 extract (pieces of the body wall were boiled with 20 times of water for 5 minutes) killed only 2 of 5 fishes (red var. of Oryzias latipes) in 24 hours at $22.5^{\circ} \mathrm{C}$. In Holothuria vagabunda, the $1: 20$ extract killed all 7 of the above fish within 19 minutes at $24^{\circ} \mathrm{C}$. Iriko (trépang preparation of Stichopus japonicus) shows somewhat stronger venom than the fresh material like that $1: 100$ extract killed all 41 of the same fish within the range of $40-130$ minutes (in the average of 59 minutes) at $22.5^{\circ} \mathrm{C}$. As to the venom of trépang details are discussed below.

4 sorts of trépang (Holothuria atra, H. axiologa, Stichopus variegatus and Thelenota ananas) of South Sea origin show relatively higher poisonous content than the other (Table 14). This is, however, in no way a serious problem, for in cooking of trépang the large amount of poison, even if it existed, should be taken away in such a way as follows: The trépang is boiled with water for about one hour and let stand overnight. On the next day the same process is repeated, and such procedure is continued usually at least for three days till it becomes soft enough to be edible. In Palao Islands among 4 trépang species mentioned above, Holothuria atra is not utilized as food, and of other 3 edible species the body wall part is eaten raw in $\dot{H}$. axiologa and in Thelenota ananas. In Stichopus variegatus, only the intestine is eaten raw mixed with salt by the natives. They gather St. variegatus (blaom) at dawn at low tide, when the intestine of the holothurian vacant (YamanouchI 1939, p. 622). Of course not all the holothurians are utilized as food by the natives in Palao Islands, and the mode of cooking is not always the same. In most cases the body wall or the flesh part is cut into pieces and eaten raw with salt or with sea water.

Besides Stichopus variegatus mentioned above, an unusual case is of Holothuria scabra, whose testis is made use of food at times by the natives of Kororu village in Palao Islands. A salted viscera of Stichopus japonicus is also relished with wine in Japan in winter season. Such common habit between Japanese and South Sea Islanders in utilizing holothurians as food, is very interesting problem in ethnography. In spite of the fact that most of the holothurian species contain saponin-like poison, they are by no means injurious as food, though whether they are eaten raw or utilized as trépang in so much as habitually hitherto adopted species being selected.

According to Assist. Prof. T. Tokioka of the Seto Marine Biological Laboratory, who visited the Tokara Islands (southwest of Kagoshima Prefecture) in 1943, the islanders eat $H$. vagabunda raw mixed with vinegar or boiled. They utilize also H. vagabunda as fish poison in such a way that mashed holothurians with stone are poured into tide pool, and after a while paralysed fishes with holothurian poison are gathered and utilized as food. 
Nothing is known of the physiological meaning of the poison in holothurian metabolism. Is there any ecological significance of the holothurian poison?

It is clearly assured that fishes may undergo paralysis and finally become to death by holothurian poison as already described, if they bite holothurians containing strong poison. In nature, it would be possible that fishes attack holothurians containing strong poison and learn by trial and error to avoid such holothurian. But in the sea and also in aquarium fishes seem to be indifferent to holothurians, because the latter would lack perhaps keys to attract fishes. In the living world there are characteristics independent of natural selection viz. devoid of selection value, and in such case consequently such characteristics would develope on its own accord in the course of evolution. The epidermal coloration and its marking pattern of holothurians belong surely to such category (YAMANOUCH 1942a). Of the question that whether holothurian poison would belong to such case or not, the author is of the opinion that holothurian poison has little ecological significance.

\section{Summary}

1. From Holothuria vagabunda SelenkA, a new poison "Holothurin" has been isolated as chemical pure crystal. This substance is composed of $\mathrm{C}, \mathrm{H}, \mathrm{O}$, but not of N. By acid hydrolysis it becomes to reduce Fehling's solution, and loses poisonous action to fish. The aglycon is soluble in organic solvents other than petroleum ether. By alkali hydrolysis it becomes glycerin-like viscious substance, and is weakened much in poisonous action than the original poison.

2. This substance in its chemical and physiological natures very much resembles plant glucoside saponin in such manner as :

(1) water soluble,

(2) strongly foaming by stirring,

(3) evoking strong sneeze to human nose when inhalated,

(4) heat resistant,

(5) producing Fehling's solution reducing product by acid hydrolysis,

(6) having strong haemolytic action to rabbit red blood cells.

3. The venom of holothurin is much stronger than that of saponin of Merck's preparation. For fresh water fish red variety of Oryzias latipes, the former is about 10 times more poisonous than the latter. The threshold concentration for complete haemolysis of rabbit red blood cells is in holothurin about $1 / 7$ of that of saponin.

4. Lethal dose of holothurin for land earthworm, frog, fish and mouse have been measured. For mouse the lethal dose in 24 hours are pro $10 \mathrm{gr}$ body weight of mouse,

$\begin{array}{lll}\text { intravenous injection } & 0.0075 \mathrm{mg} .(1: 1,330,000) \\ \text { subcutaneous injection } & 0.7 & \mathrm{mg} \cdot(1: 14,300) \\ \text { peros application } & 4.0 & \mathrm{mg} \cdot(1: 2,500)\end{array}$


5. Haemolytic action of holothurin is much reduced by the presence of cholesterin, and this reduction is roughly proportional to the amount of cholesterin present.

6. Holothurin distributes in all parts or organs of Holothuria vagabunda including the body fluid. The amount of poisonous content is different according to each type of organs. In body fluid, major amount of poison is located in blood cells.

7. Of 27 holothurian species in Japan and in South Sea Islands, 24 species have been proved to contain substance poisonous to fish and 22 species to have haemolytic action, that is more than $80 \%$ holothurian species have been proved to contain more or less poison.

8. 13 sorts of trépang preparation have been examined whether they contain poison or not. All sorts examined have been proved to contain poison. Notwithstanding the presence of poisonous substance, no case is hitherto reported as to poisoning. The reason for this has been discussed.

9. The poison contained in holothurians are not common among species. They are specific to each species. No relation has been found as to the presence or absence or as to the grade of the content of poison between genera of holothurians.

10. Poisons contained in holothurians seem to have little ecological significance. There should be some meaning of the presence of poison in the metabolism of holothurians, considering the chemical nature of holothurin.

\section{LITERATURE CITED}

Mitsukuri, K. 1912. Studies on actinopodous Holothurioidea. Journ. Coll. Sci. Imp. Univ. Tokyo, vol. 29 , art. 2, p. 140.

Ransom, F. 1901. Saponin und sein Gegengift. Deut. Med. Wochensch., Bd. 27, No. 13, p. 194.

SelenkA, E. 1867. Beiträge zur Anatomie und Systematik der Holothurien. Zeitsch. wiss. Zool., Bd. 17, p. 334 .

YAMANOUCHI, T. 1939. Ecological and physiological studies on the holothurians in the coral reef of Palao Islands. Palao Trop. Biol. Sta. Studies, vol. 1, no. 4. p. 622.

1942 a. Variation of the coloration and the pattern in holothurians. (in Japanese). Kagaku Nan'yo, vol. 5, no. 1, p. 74 .

1942 b. On the poison extracted from holothurians. (in Japanese). Teikoku Gakushiin Hôkoku, 1942 p. 73.

$1943 \mathrm{a}$. On the distribution of poison in the body of holothurians. (in Japanese). Zool. Mag., vol. 55, p. 87.

1943 b. On the poison contained in holothurians. (in Japanese). Folia Pharmacologica

Japonica, vol, 38, fasc. II, p. $115 \S$. 